Original Article

\title{
ANTIBACTERIAL ACTIVITY OF MENTHA PULEGIUM ESSENTIAL OIL AGAINST AVIAN ISOLATED ESBL PRODUCING BACTERIA AND ITS SYNERGISTIC POTENTIAL WITH ANTIBIOTICS
}

\author{
FATIMA YAHIAOUI ${ }^{1}$, QADA BENAMEUR ${ }^{2}$, MERIEM HIND BEN-MAHDI1,3
}

\author{
${ }^{1}$ Laboratoire de Recherche, Santé and Productions Animales, Ecole Nationale Supérieure Vétérinaire-Algiers, Algeria, ${ }^{2}$ Faculté Des \\ Sciences de la Nature et de la Vie, University of Mostaganem, Algeria, ${ }^{3}$ Ecole Préparatoire en Sciences de la Nature et de la Vie EPSNV- \\ Algier, Algeria \\ Email: yahiaoui.fatima@gmail.com
}

Received: 14 Jan 2017 Revised and Accepted: 20 Apr 2017

\section{ABSTRACT}

Objective: The aim of this study was to evaluate the antibacterial effect of Algerian Mentha pulegium essential oil against extended-spectrum $\beta$ lactamases (ESBL) producing bacteria isolated from avian livestock. The synergistic interactions between conventional antibiotics and Mentha pulegium essential oil were assessed.

Methods: Essential oil composition was determined by gas chromatograph-flame ionization detector (GC/FID), gas chromatograph-mass spectrometer (GC/MS) analysis.

Antibacterial activity of Mentha pulegium essential oil against ESBL producing bacteria was investigated by disc diffusion assay. Minimum inhibitory concentration (MIC) of essential oil and it synergistic interaction with conventional antibiotics were determined by micro-broth dilution method and checkerboard test, respectively.

Results: The results indicate that Mentha pulegium essential oil with a high amount of pulegone (88.78\%) had high inhibitory activity against the tested strains and particularly displays a satisfactory action against the studied ESBL producing bacteria from animal origin, with a diameter ranging from 13 to $26 \mathrm{~mm}$. Out of 51 combinations tested between essential oil and antibiotics $60.78 \%$ showed total synergy, $13.72 \%$ had presented a partial synergy. The best antibacterial activities were obtained with the combination of Mentha pulegium essential oil and cefazolin, cefotaxime and gentamycin.

Conclusion: This study allowed concluding that Mentha pulegium essential oil showed not only satisfactory antibacterial properties, but also acts synergistically combined with conventional antibiotics, which make it a promising alternative to antimicrobial drugs; beside that, it might reduce the minimum effective dose of the drugs which minimizes their possible side effects.

Keywords: Mentha pulegium, Essential oil, Pulegone, ESBL bacteria, Antibacterial, Synergy, Antibiotics

(C) 2017 The Authors. Published by Innovare Academic Sciences Pvt Ltd. This is an open access article under the CC BY license (http://creativecommons.org/licenses/by/4.0/) DOI: http://dx.doi.org/10.22159/ijpps.2017v9i6.17092

\section{INTRODUCTION}

The extended-spectrum $\beta$-lactamases (ESBL) producing bacteria are plasmid mediated enzymes that are enable to hydrolyze and inactivate a wide variety of beta-lactams including third generation cephalosporins, penicillins, and aztreonam [1]. Production of extended-spectrum $\beta$-lactamases (ESBLs) is one of the major causes of antibiotic resistance in these bacteria [2]. Their emergence in animal livestock is of a major medical and economic importance, indeed, antimicrobial resistance threatens public health and confronts humans at a therapeutic risk impasse, especially for zoonotic bacterial infections, and moreover, it causes several therapeutic failures in livestock which can lead to great economic losses.

The battle against bacterial infections involving antibiotic-resistant microorganisms has thus become a critical concern in the veterinary field and so, the development of alternative strategies becomes mandatory. The exploration of natural resources appears to be more promising, essential oil extracted from medicinal herbs and food plants have been highlighted as natural substances having a rich source of compounds with effective antimicrobial and antibiotic properties.

Mentha pulegium is one of medicinal Mentha species with good antimicrobial properties, it is commonly known as pennyroyal. It is native from Europe, North Africa and in minor and near East Asia [3]. In Algeria, where it is an endemic plant, leaves are widely used both as a tea brewing and as flavoring in salads or cooked food. Moreover, it is used in folk medicine in several ways, actually, it is known to be a good digestive tonic, it stimulates digestive juices, relieves flatulence and colic. It is also a good remedy for headaches and for respiratory infections (cold, sinusitis, bronchitis, tuberculosis) and a powerful stimulant to the uterine muscle encouraging menstruation [4]. It can be used externally to relieve rheumatic conditions including gout [5]. Besides that, pennyroyal leaves, both fresh and dried, are especially noted for repelling insects [6].

Previous studies have reported satisfactory antibacterial activities of Mentha pulegium essential oil; actually, it shows a better activity on Gram positive bacteria [7]. Moreover, Teixeira et al. (2007) highlighted a good growth inhibition of Gram negative bacteria including E. coli [8]. To date, few studies have been conducted on its possible inhibitory effect on multidrug resistant bacteria especially ESBL producing one. Accordingly to this, the purpose of this study was to determine the antibacterial activity of Mentha pulegium essential oil against different multidrug resistant bacteria particularly on ESBL producing strains, isolated from chicken livestock, and to assess the antimicrobial possible synergistic effect of the association between classical antibiotics and Mentha pulegium essential oil.

\section{MATERIALS AND METHODS}

Reagents and chemicals

Muller Hinton agar and Muller Hinton broth were purchased from Conda, Spain, [3-(4.5-dimethylthiazol-2-yl)-2.5-diphenyltetrazolium bromide (MTT) and tween 80 were purchased form Sigma-Aldrich Chemical USA. 


\section{Plant material}

Flowering aerial parts of Mentha pulegium were collected from Adekar area (N 36.7172164, E 4.6690730, Bejaia-ALGERIA) in summer 2013. The voucher specimen was identified by the Department of Botany of Ecole Nationale Superieure d'Agronomie (ENSA, El Harrach), and deposited at the Herbarium of Santé et productions animales Laboratory research (ENSV, Algiers) under number $027 / 13$. The samples were dried in the shade away from light at room temperature for 7 to $10 \mathrm{~d}$.

\section{Essential oil extraction procedure, GC/FID and GC/MS analyses}

After drying, the samples were ground and hydrodistilled for $3 \mathrm{~h}$ using a clevenger-type apparatus. The essential oils were stored in sterile amber bottle at $4{ }^{\circ} \mathrm{C}$ until analyses. The Mentha pulegium essential oil analysis was performed at Lexva analytique laboratory (Saint-Beauzire, France) under the operating conditions described below:

The essential oil of Mentha pulegium was analysed on an agilent gas chromatograph-flame ionization detector (GC-FID) model 6890, equipped with an apolar column (DB5 MS: $20 \mathrm{~m}$ length 0,18 $\mathrm{mm}$ internal diameter $0,18 \mu \mathrm{m}$ film thickness), programmed from $50^{\circ} \mathrm{C}(3,2 \mathrm{~min})$ to $300^{\circ} \mathrm{C}$ at $10^{\circ} \mathrm{C} / \mathrm{min}$. Injector temperature were $280^{\circ} \mathrm{C}$. The essential oil was diluted in acetone in $4 \%(\mathrm{v} / \mathrm{v})$, and $2 \mu \mathrm{l}$ was injected in split mode $(1 / 120)$. Hydrogen was used as a carrier gas $(1.1 \mathrm{ml} / \mathrm{min})$ [9].

Mass spectrometry was performed on an agilent gas chromatographmass spectrometer (GC/MS) model 7890/5975 C, programmed with the same conditions as for GC-FID (as described above). The essential oil was diluted in acetone in $4 \%(\mathrm{v} / \mathrm{v})$, and $2 \mu \mathrm{l}$ was injected in split mode $(1 / 150)$. Hydrogen was used as a carrier gas $(1.1 \mathrm{ml} / \mathrm{min})$. Mass spectral data were acquired in the scan mode in the mass range 33-550.

The percentage was calculated from the peaks area given by the GC/FID without the use of correction factor. The components of the oil were identified by a combined search of retention times (lab library) and mass spectra (Library NIST 225000 records).

\section{Antibacterial activities and synergy test}

\section{Bacterial strains}

Different bacterial strains from the American type culture collection (ATCC) standard strains (E. coli ATCC 25922, Staphylococcus aureus ATCC 25923 and Pseudomonas aeruginosa ATCC 27853), obtained from Institute Pasteur of Algiers, were tested.

Besides that, thirty one multi-resistant veterinary clinical isolates of different bacterial strains were studied (table 1) including 18 ESBL producing bacteria; their resistance profiles have been previously established according to clinical and laboratory standards institute (CLSI) [10].

\section{Disc diffusion assay}

The disk diffusion method was employed as a qualitative screening test for the determination of antimicrobial activities of Mentha pulegium essential oil, according to the method described by Kirby and Bauer [11].

The bacterial cultures were first grown on nutrient agar plates at 37 ${ }^{\circ} \mathrm{C}$ for 18 to $24 \mathrm{~h}$. Some colonies of each bacterial tested strain were transferred into physiological water and the obtained bacterial suspensions were adjusted to $1 \times 10^{7} \mathrm{CFU} / \mathrm{ml}(1 / 10$, v/v; pattern 0.5 of McFarland standard). Then, it was spread into Muller Hinton agar, using a sterile cotton swab.

Subsequently, sterile disks of $6 \mathrm{~mm}$ diameter were placed in the surface of Petri dishes and impregnated with essential oil. Negative control was prepared using water and tween 80 at a concentration of $0.01 \%$. Reference antibiotics were used as a positive control for each tested strain. The Petri dishes were incubated at $37{ }^{\circ} \mathrm{C}$ for $24 \mathrm{~h}$. All determinations were performed in triplicate. Antibacterial activity was evaluated by measuring the radius of the inhibition zones.

\section{Minimal inhibitory concentration (MIC), Minimal bactericidal concentration (MBC)}

The sensitive bacteria to Mentha pulegium essential oil were selected for the micro dilution assay in order to determine the minimal inhibitory and bactericidal concentrations. Moreover, the time kill assay was performed to establish the dynamic of action of Mentha pulegium essential oil against these same bacteria.

The MIC and MBC assays were performed using a serial microplate dilution method as described by Eloff with some variations [12]. Briefly, serial twofold dilutions of Mentha pulegium essential oil in Mueller-Hinton broth-tween $800.01 \%$ was prepared in 96-well microplate, over the range $18.56 \mathrm{mg} / \mathrm{ml}$ to $0.036 \mathrm{mg} / \mathrm{ml} .100 \mu \mathrm{l}$ of an actively growing culture of the tested organism were added to each of the dilutions, the microplate was sealed and incubated $18 \mathrm{~h}$ at $37^{\circ} \mathrm{C}$.

After incubation, $40 \mu \mathrm{l}$ of $0.2 \mathrm{mg} / \mathrm{ml}$ of MTT [3-(4.5-dimethylthiazol2-yl)-2.5-diphenyltetrazolium bromide, Sigma Chemicals] solution, was added to each of the wells. Microplate was examined after additional incubation of 30-120 min. Bacterial growth was indicated by the purple color of the MTT reduced to formazan. The lowest concentration at which a decrease in the purple color was observed compared to the next dilution was taken as the MIC value.

The samples showing no bacterial growth were streaked on MHA agar plates, which were incubated for $24 \mathrm{~h}$ at $37{ }^{\circ} \mathrm{C}$ and finally examined for $99.9 \%$ killing. The minimal bactericidal concentration was thus deduced.

\section{Time-kill assay}

Time-kill assay was performed according to the method described by Viljoen et al. [13]. Activities of essential oils against Staphylococcus aureus ATCC 25923, E. coli ATCC 25922, ESBL producing bacteria including E. coli, Proteus mirabilis, Salmonella pullorum and Enterobacter cloacae strains were evaluated by measuring the reduction in the number of $\mathrm{CFU} / \mathrm{ml}$ over $2 \mathrm{~h}$.

An initial inoculum of $5 \times 10^{6} \mathrm{CFU} / \mathrm{ml}$ was prepared and $1 \mathrm{ml}$ was added to $9 \mathrm{ml}$ of MHB containing both the essential oils and tween 80 (tests) or tween 80 only (control).

Essential oils were used at a final concentration equal to their MIC and their MBC. Tween 80 was added to both tests and control at a final concentration of $0.01 \%(\mathrm{v} / \mathrm{v})$. The test tubes were incubated with agitation at $37^{\circ} \mathrm{C}$ and samples $(100 \mu \mathrm{l})$, taken in duplicate at 0 , $10,30,60,90$ and $120 \mathrm{~min}$, were serially 10 -fold diluted, plated onto MHA and the total viable counts were determined after overnight incubation at $37^{\circ} \mathrm{C}$.

\section{Synergistic interaction between Mentha pulegium essential oil and antibiotic}

Broth micro dilution checkerboard method was used to determine the potential synergistic interactions between Mentha pulegium essential oil and antibiotics on 96 well-plate [14, 15]. Nine conventional antibiotics have been used (table 4).

In this experiment, Staphylococcus aureus ATCC 25923, E. coli ATCC 25922 and 4 ESBL producing bacteria including E. coli, Proteus mirabilis, Salmonella pullorum, and Enterobacter cloacae were studied. The tested dilutions were based on the MIC of the two antimicrobial agents which are mixed together so that the wells of the plate could contain various concentration combinations of the two compounds.

Eight serial two-fold dilutions (from MIC to MIC/128) of each antimicrobial agent were prepared.

$100 \mu \mathrm{l}$ aliquots of the first antimicrobial agent dilution were added in a vertical orientation, and $100 \mu \mathrm{l}$ aliquots of the second antimicrobial agent dilution were added in a horizontal orientation. $100 \mu \mathrm{l}$ of fresh bacterial suspension $\left(\approx 10^{6} \mathrm{CFU} / \mathrm{ml}\right)$ were added to each well and cultured at $37^{\circ} \mathrm{C}$ for $24 \mathrm{~h}$.

The results of the checkerboard assay were used for calculation of the fractional inhibitory concentration (FIC) index for two antimicrobials in combination according to the following formula:

$$
\begin{aligned}
\text { FIC Index }=\frac{\text { MICessential oilincombination }}{\text { MICessential oilalone }} \\
+\frac{\text { MIC antibiotic in combination }}{\text { MIC antibiotic alone }}
\end{aligned}
$$




\section{RESULTS}

\section{Chemical composition}

Chemical analysis of Mentha pulegium essential oil revealed 26 different compounds accounting for $97.71 \%$ of the essential oil composition (table 1). The major constituent of the studied Mentha pulegium essential oil is represented by pulegone $(88.78 \%)$.

\section{Antibacterial activities and synergy test \\ Disc diffusion assay}

The disk diffusion method was employed as a qualitative screening test for the determination of antimicrobial activities of Mentha pulegium essential oil, antibacterial activity was evaluated by measuring the radius of the inhibition zones ( $\mathrm{mm}$ ) (table 2).

Table 1: Mentha pulegium essential oil composition

\begin{tabular}{llll}
\hline Compounds & GC/FID\% & Compounds & GC/FID \% \\
\hline Alpha-Pinene & 0.235 & Neo-menthol & 2.083 \\
Camphene & 0.016 & Trans-dihydrocarvone & 1.364 \\
Sabinene & 0.054 & Pulegone & 88.78 \\
Beta-pinene & 0.196 & 8-hydroxy-4(5)-para menthen3 one & 0.453 \\
Myrcene & 0.073 & Piperitenone & 0.329 \\
3-Octanol & 1.207 & Inknown MW & 0.087 \\
Para-cymene & 0.026 & Beta-caryophyllene & 0.104 \\
Limonene & 0.372 & Alpha-humulene & 0.180 \\
Eucalyptol & 0.068 & Germacrene-D & 0.020 \\
Trans-Iso-Limonene & 0.020 & Mintfuranone & 0.029 \\
Menth-3-ene8-ol-para & 0.236 & Oxyde de caryophyllene & \\
Menthone & 0.919 & Humulene 1,5epoxyde & \\
Menthofuran & 0.044 & & 0.187 \\
Iso-menthone & 0.211 & Total identified \\
\hline
\end{tabular}

Table 2: Diameter of inhibition zones ( $\mathrm{mm})$ obtained by the agar diffusion method

\begin{tabular}{|c|c|c|c|c|}
\hline Bacterial strain & $\begin{array}{l}\text { Antibiotic control } \\
\text { IMP }\end{array}$ & $\begin{array}{l}\text { Antibiotic control } \\
\text { GTC }\end{array}$ & $\begin{array}{l}\text { Negative control } \\
\text { tween }\end{array}$ & $\begin{array}{l}\text { Mentha pulegium essential } \\
\text { oil }\end{array}$ \\
\hline Staphylococcus aureus ATTC 25923 & - & $30 \pm 1.1$ & $\leq 6$ & $35 \pm 0.7$ \\
\hline E. coli ATTC25922 & - & $25 \pm 0.5$ & $\leq 6$ & $17 \pm 1.41$ \\
\hline $\begin{array}{l}\text { Pseudomonas aerugenosa ATTC } \\
27853\end{array}$ & - & - & $\leq 6$ & $7 \pm 0$ \\
\hline Staphylococcus aureus & - & $24 \pm 0.4$ & $\leq 6$ & $16 \pm 0.7$ \\
\hline Staphylococcus epidermidis & - & $19 \pm 0.7$ & $\leq 6$ & $14 \pm 0$ \\
\hline Klebsiella pneumonia & - & ND & $\leq 6$ & $12 \pm 0.7$ \\
\hline Salmonella dublin, & - & $18 \pm 0.3$ & $\leq 6$ & $13 \pm 0$ \\
\hline Salmonella enteridis, & - & $19 \pm 0.3$ & $\leq 6$ & $13 \pm 0$ \\
\hline Salmonella thyphi, & - & $19 \pm 0.4$ & $\leq 6$ & $10 \pm 0$ \\
\hline Salmonella infantis, & - & $19 \pm 0.3$ & $\leq 6$ & $12 \pm 0.7$ \\
\hline Salmonella gallinarum & - & $25 \pm 0.7$ & $\leq 6$ & $10 \pm 0$ \\
\hline Proteus mirabilis (1) & - & ND & $\leq 6$ & $14 \pm 0.7$ \\
\hline Shigella $s p$ & - & $23 \pm 0.4$ & $\leq 6$ & $12 \pm 1$ \\
\hline Yersinia $s p$ & - & $25 \pm 0.6$ & $\leq 6$ & $11 \pm 0.8$ \\
\hline Providenciasp, & - & $23 \pm 0.4$ & $\leq 6$ & $12 \pm 0.7$ \\
\hline Enterobacter cloacae (1) & - & $24 \pm 0.3$ & $\leq 6$ & $14 \pm 1$ \\
\hline Salmonella pulorum ESBL & $\geq 30$ & - & $\leq 6$ & $13 \pm 0.12$ \\
\hline E. coli ESBL (1) & $\geq 30$ & - & $\leq 6$ & $15.33 \pm 0.7$ \\
\hline E. coli ESBL (2) & $\geq 30$ & - & $\leq 6$ & $12.66 \pm 0.7$ \\
\hline E. coli ESBL (3) & $\geq 30$ & - & $\leq 6$ & $14 \pm 0.2$ \\
\hline E. coli ESBL (4) & $\geq 30$ & - & $\leq 6$ & $13.66 \pm 0.2$ \\
\hline E. coli ESBL (5) & $\geq 30$ & - & $\leq 6$ & $10 \pm 0.24$ \\
\hline E. coli ESBL (6) & $\geq 30$ & - & $\leq 6$ & $14.66 \pm 0.57$ \\
\hline E. coli ESBL (7) & $\geq 30$ & - & $\leq 6$ & $14.33 \pm 1.12$ \\
\hline E. coli ESBL (8) & $\geq 30$ & - & $\leq 6$ & $11.33 \pm 0.8$ \\
\hline E. coli ESBL (9) & $\geq 30$ & - & $\leq 6$ & $13 \pm 1$ \\
\hline E. coli ESBL (10) & $\geq 30$ & - & $\leq 6$ & $12.66 \pm 0.76$ \\
\hline E. coli ESBL (11) & $\geq 30$ & - & $\leq 6$ & $12.66 \pm 0.76$ \\
\hline E. coli ESBL (12) & $\geq 30$ & - & $\leq 6$ & $14 \pm 1$ \\
\hline E. coli ESBL (13) & $\geq 30$ & - & $\leq 6$ & $16.66 \pm 0,23$ \\
\hline Proteus mirablis ESBL (2) & $\geq 30$ & - & $\leq 6$ & $26.66 \pm 0.76$ \\
\hline Proteus mirablis ESBL (3) & $\geq 30$ & - & $\leq 6$ & $16.66 \pm 0.23$ \\
\hline Enterobacter cloacae ESBL (2) & $\geq 30$ & - & $\leq 6$ & $12 \pm 0.46$ \\
\hline Enterobacter cloacae ESBL (3) & $\geq 30$ & - & $\leq 6$ & $13.16 \pm 0,57$ \\
\hline
\end{tabular}

Values are given as mean \pm standard deviation $(n=3), I M P=$ imipenem $/ G T C=$ gentamicin $\mathrm{ND}=$ not determined

The obtained results revealed that Mentha pulegium essential oil had wide antibacterial spectrum, it inhibited the growth of all tested bacteria with ranging magnitudes $(10-35 \mathrm{~mm})$, except for
Pseudomonas aeruginosa which shown a very low sensibility (table 2). No inhibition zone was observed for the negative control $(0.01 \%$ tween 80). 
In which concerns the other tested bacteria, our study has shown for the first time that Mentha pulegium essential oil displays a satisfactory action against the studied ESBL producing bacteria (12/18) from animal origin, with a diameter ranging from 13 to $26 \mathrm{~mm}$.

\section{Minimal inhibitory concentration (MIC), Minimal bactericidal concentration (MBC)}

The sensitive bacteria to Mentha pulegium essential oil were selected to the micro dilution assay in order to determine the minimal inhibitory and bactericidal concentrations. Moreover, the time kill assay was performed to establish the dynamic of action of Mentha pulegium essential oil against these same bacteria.

The minimum inhibitory concentrations (MIC) were ranging from $0.14 \mathrm{mg} / \mathrm{ml}$ to $2.32 \mathrm{mg} / \mathrm{ml}$ (table 3 ).

MIC values are close to MBC values, so that the MBC/MIC ratios of the different strains are lower than 4 (table 3 ).

\section{Time kill assay}

Preliminary treatment of bacteria with Mentha pulegium essential oil used at a concentration equivalent to their MIC has shown a rapid decrease in the bacterial growth rate, the bactericidal end point was obtained after one hour at last, whereas, a total inhibition of growth was noted after $10 \mathrm{~min}$ when a concentration equivalent to the MBC were used, these observations are valuable for all tested bacteria including ESBL producing ones.

\section{Synergistic interaction between Mentha pulegium essential oil and antibiotic}

The results of the checkerboard assay are interpreted by calculating the fractional inhibitory concentration (FIC) index. FIC Index values were interpreted as following: Synergy (FICI $\leq 0.5)$, additive effect $(0.5$ $\leq \mathrm{FICI} \geq 1)$, indifferent or antagonistic effect $(1 \leq \mathrm{FICI} \geq 2),[16,17]$.

The results of synergistic effect between Mentha pulegium essential oil and antibiotics are given in table 4.

Table 3: Minimal inhibitory concentrations MIC (mg/ml), minimal bactericidal concentrations $\mathrm{MBC}(\mathrm{mg} / \mathrm{ml})$ and $\mathrm{MBC} / \mathrm{MIC} \mathrm{ratios}$ of Mentha pulegium essential oil

\begin{tabular}{lll}
\hline & MIC $\mathbf{( m g / m l )}$ & MBC $(\mathbf{m g} / \mathbf{m l})$ \\
\hline Staphylococcus aureus ATCC 25923 & $0.29 \pm 0.16$ & $0.58 \pm 0.16$ \\
Staphylococcus epidermidis & $0.58 \pm 0.16$ & $1.16 \pm 0.33$ \\
E. coli ATCC25922 & $1.16 \pm 0.33$ & $2.32 \pm 0.66$ \\
Proteus mirabilis (ESBL) 3 & $2.32 \pm 0.66$ & $4.64 \pm 1.33$ \\
Proteus mirabilis (ESBL) 2 & $2.32 \pm 0.66$ & $2.32 \pm 0.66$ \\
E. coli (ESBL) 3 & $1.16 \pm 0.33$ & $2.32 \pm 0.66$ \\
E. coli (ESBL) 6 & $1.16 \pm 0.66$ & $2.32 \pm 0.66$ \\
E. coli (ESBL) 7 & $1.16 \pm 0.66$ & $2.32 \pm 0.66$ \\
E. coli (ESBL) 1 & $0.58 \pm 0.16$ & $1,16 \pm 0.33$ \\
E. coli (ESBL) 12 & $1.16 \pm 0.66$ & $2.32 \pm 0.66$ \\
E. coli (ESBL) 13 & $0.58 \pm 0.16$ & $1.16 \pm 0.33$ \\
Salmonella dublin & $2.32 \pm 0.66$ & $2.32 \pm 0.66$ \\
Salmonella enteridis & $0.58 \pm 0.16$ & $1.16 \pm 0.33$ \\
Salmonella pullorum (ESBL) & $2.32 \pm 0.66$ & 2 \\
Enterobacter cloacae (ESBL) 3 & $2.32 \pm 0.66$ & $2.32 \pm 0.66$ \\
\hline
\end{tabular}

Values are given as mean \pm standard deviation, $(n=3)$

Table 4: Synergistic interaction between Mentha pulegium essential oil and antibiotics against selected bacteria, FIC Index of different combinations of antibiotics and $M \mathrm{MP}^{\mathrm{b}}$ essential oil

\begin{tabular}{|c|c|c|c|c|c|c|}
\hline & S. aureus ATCC 25923 & E. coli ATCC 25922 & $\begin{array}{l}\text { E. coli } \\
(E S B L 1)\end{array}$ & P. mirabilis (ESBL2) & $\begin{array}{l}\text { S. pullorum } \\
\text { (ESBL) }\end{array}$ & $\begin{array}{l}\text { E. cloacae } \\
\text { (ESBL3) }\end{array}$ \\
\hline MP+amoxicillin & $0.56 \pm 0.1^{d}$ & $0.5 \pm 0.1^{\mathrm{c}}$ & $0.5 \pm 0.1^{\mathrm{c}}$ & $0.31 \pm 0.1^{\mathrm{c}}$ & $1.5 \pm 0.5^{\mathrm{e}}$ & $1.25 \pm 0.5^{\mathrm{e}}$ \\
\hline MP+penicillin & ND & ND & ND & $0.06 \pm 0.01^{c}$ & $1.5 \pm 0.5^{\mathrm{e}}$ & $0.75 \pm 0.15^{\mathrm{d}}$ \\
\hline MP+cefotaxime & $0.5 \pm 0.1^{c}$ & $0.093 \pm 0.01^{\mathrm{c}}$ & $0.13 \pm 0.06^{c}$ & $0.5 \pm 0.1^{\mathrm{c}}$ & $0.25 \pm 0.1^{\mathrm{c}}$ & $0.093 \pm 0.01^{\mathrm{c}}$ \\
\hline MP+cefazolin & $0.18 \pm 0.06^{\mathrm{c}}$ & $0.07 \pm 0.01^{\mathrm{c}}$ & $0.07 \pm 0.01^{\mathrm{c}}$ & $0.25 \pm 0.1^{c}$ & $0.5 \pm 0.1^{\mathrm{c}}$ & $0.325 \pm 0.1^{c}$ \\
\hline MP+tetracycline & $0.18 \pm 0.06^{c}$ & $0.5 \pm 0.1^{\mathrm{c}}$ & $0.37 \pm 0.1^{c}$ & $0.25 \pm 0.1^{c}$ & $1 \pm 0.5^{\mathrm{d}}$ & $0.75 \pm 0.15^{d}$ \\
\hline MP+imipenem & $0.18 \pm 0.06^{c}$ & $0.5 \pm 0.1^{\mathrm{c}}$ & $0.187 \pm 0.06^{c}$ & $0.06 \pm 0.01^{c}$ & $0.625 \pm 0.15^{d}$ & $1 \pm 0.5^{\mathrm{d}}$ \\
\hline MP+enrofloxacin & $2 \pm 0.5^{\mathrm{e}}$ & $2 \pm 0.5^{\mathrm{e}}$ & $2 \pm 0.5^{\mathrm{e}}$ & $2 \pm 0.5^{e}$ & $1.5 \pm 0.5^{\mathrm{e}}$ & $1 \pm 0.5^{\mathrm{d}}$ \\
\hline MP+marbofloxacin & $2 \pm 0.5^{\mathrm{e}}$ & $2 \pm 0.5^{\mathrm{e}}$ & $2 \pm 0.5^{e}$ & $2 \pm 0.5^{\mathrm{e}}$ & $1.5 \pm 0.5^{\mathrm{e}}$ & $0.325 \pm 0.1^{c}$ \\
\hline MP+gentamycin & $0.375 \pm 0.1^{\mathrm{c}}$ & $0.18 \pm 0.06^{c}$ & $0.18 \pm 0.06^{c}$ & $0.18 \pm 0.06^{c}$ & $0.18 \pm 0.06^{c}$ & $0.18 \pm 0.06^{c}$ \\
\hline
\end{tabular}

ND: not determined, Values are given as mean \pm standard deviation. $(\mathrm{n}=3)$, aFractional inhibitory Concentration Index, ${ }^{\mathrm{b}}$ Mentha pulegium, ctotal synergy, dadditive effect, eindifferent or antagonistic

\section{DISCUSSION}

Chemical analyses of the studied essential oil showed that it belongs to the pulegone type, it contained mainly oxygenated monoterpenes represented by pulegone with a rate of $88.78 \%$, no study has reported before such high pulegone rate.

Worldwide, several studies on Mentha pulegium essential oil composition establish three chemotypes: pulegone type, piperitenone/ piperitone type and isomenthone/neoisomenthol type [18].

Previously in Algeria, the compounds of Mentha pulegium essential oil have been identified by Beghidja et al., who showed a difference on its constituents depending on the region of cultivation; actually, it appears that Algerian oils can be classified following two chemotypes: the first is the pulegone type with $52-87 \%$ yield of pulegone and some variations of the other constituents and the second chemotype which is poorer in pulegone and relatively rich in the non-oxygenated terpenic fraction [19].

Studies conducted in Bulgaria, Tunisia, Morocco, India, Serbia and Iran, have reported pulegone chemotype but in lower proportions of pulegone compared to the presently studied essential oil [18, 20-25]. The high amount of pulegone can be attributed to the harvest area which is located in high altitude.

It is known that variability in the chemical composition of Mentha pulegium essential oil through different studies is probably due to the high chemical variability of extracted oils from Mentha spp, 
induced by various factors, such as the age of the plant, variety of species, geographic region, soil composition and processing conditions [26, 27]. Moreover, this variability confers to each essential oil different biological effects.

The antibacterial investigation on Mentha pulegium essential oil showed that it exhibits a potent antibacterial activity against a wide panel of bacteria including multi-resistant ones except for Pseudomonas aeruginosa which is known to be the least sensitive bacteria to essential oils $[28,29]$. According to Longbottom et al., its resistance appears to be due to its external membrane structure, particularly impermeable to essential oil molecules and the action of efflux mechanisms, which enhance the protection of the bacteria against the essential oil action [30].

Staphylococcus aureus was the most sensitive to essential oil, it was followed by Staphylococcus epidermitidis and some other Enterobacteria (E. coli, Enterobacter cloacae, Proteus mirabilis, Salmonella strains: S. dublin, S. enteritidis, S. pullorum). Concerning the other Enterobacteria (Salmonella gallinarum, Salmonella thyphi, Salmonella infantis, Providencia sp, Klebsiella sp, Shiguella sp, Yersinia $s p$ ) we noted a moderate response. Gram positive species are more sensitive to natural products than Gram-negative bacteria, because of the hydrophobic lipopolysaccharide in the outer Gram negative membrane's which provides protection against different agents [31].

Concerning EBSL strains represented by E. coli, P. mirabilis, $S$. pullorum, E. cloacae, our study shows for the first time that Mentha pulegium essential oil displays a satisfactory action against the studied ESBL producing bacteria $(12 / 18)$ from animal origin, with a diameter ranging from 13 to $26 \mathrm{~mm}$.

The reported differences in susceptibility may be due to the differences in the cell wall composition and/or genetic content of their plasmids [32].

Some studies have proved the antibacterial effects of essential oil on human ESBL producing bacteria, actually, it has been described an interesting activity of natural compounds including clove, cinnamon, oregano, green tea against E. coli and Klebsiella pneumonia ESBL producing bacteria [33-36].

It was reported through this study that Mentha pulegium essential oil displays a bactericidal activity [36].

The MIC values obtained in our study are lower than those reported by Teixeira et al. [8], who noted respectively a MIC of 3.2 and 3.8 $\mathrm{mg} / \mathrm{ml}$ for E. coli and S. typhimurium.

However, it seems difficult to compare these results with ours, because of the difference in essential oil composition of the chemotypes studied and the different strains tested (ESBL producing bacteria from animal origin). Thereby, Mahboubi et Haghi [7] using piperetone chemotype have noted a significant activity against Gram-positive bacteria with inhibition zones ranging from 8-21 mm and no activity against Escherichia coli and Salmonella typhimurium. Furthermore, they noted the lowest MIC with values of $0.25-4 \mu \mathrm{l} / \mathrm{ml}$. On the opposite, Teixeira et al. and Marzouk et al. reported a satisfactory inhibition of E. coli $[8,37]$.

The objective of time kill assay was to characterize the antibacterial kinetic activity of essential oil. The obtained results highlighted a rapid decrease in the bacterial growth rate, indeed the bactericidal end point was obtained after one hour at last, whereas, a total inhibition of growth was noted after $10 \mathrm{~min}$ when a concentration equivalent to the MBC were used, these observations mean that Mentha pulegium essential oil displays an immediate bactericidal action.

The bactericidal action of Mentha pulegium essential oil might be attributed to the high amount of pulegone (88.78\%), Duru et al., have previously demonstrated a strong antimicrobial activity of pulegone against a set of bacteria, including S. typhimurim and E. coli [38].

Moreover, because of the complex composition of essential oils, multiple nonspecific cellular targets might be implicated [39]. In bacteria, the permeabilization of the membrane is associated with loss of ions and reduction of membrane potential, collapse of the proton pump and depletion of the ATP pool. Furthermore, essential oils can coagulate the cytoplasm and damage lipids and proteins generating thus damage to the cell wall and membrane which lead to the leakage of macromolecules and to bacteria lysis [40].

Out of 51 combinations tested between Mentha pulegium essential oiland nine antibiotics (enrofloxacin, gentamicin, amoxicillin, penicillin, cefazolin, cefotaxime, tetracycline, marbofloxacin, imipenem): 31 (60.78\%) showed total synergy, 7 (13.72\%) had partial synergistic interaction and $13(25.49 \%)$ had no effect. The best antibacterial activities were obtained with the combination of Mentha pulegium essential oil and cefazolin, cefotaxime and gentamycin in which FIC index ranged from 0.07 to 0.5 and the total synergy effect obtained with this combination was observed for all studied strains. The combination of Mentha pulegium essential oil with amoxicillin, tetracycline and imipenem showed total synergy against all the tested strains, excepting Salmonella and Enterobacter (FICI $\geq 0.75$ ).

The ESBL producing bacteria are plasmid mediated enzymes that are enable to hydrolyze and inactivate a wide variety of betalactams including third generation cephalosporins, penicillins, and aztreonam [41]. Their large emergence since last decades both in animals and humans threatens public health by many serious incurable infections because of their high resistance to conventional antibiotics.

Accordingly to this, the objective of our study was to explore the potential synergistic effect of Mentha pulegium essential oil with conventional antibiotics.

The obtained results showed that Mentha pulegium essential oil displays a bactericidal effect especially against ESBL producing bacteria and reported potential synergistic effects with conventional antibiotics like amoxicillin, cefazolin, cefotaxime, gentamycin.

We demonstrated for the first time synergy between Mentha pulegium essential oil and antibiotics tested on avian multi-resistant clinical isolates.

The synergistic effect of Mentha pulegium essential oil combined with amoxicillin, cefazolin and cefotaxime is promising, it can lead to recover these antibiotics efficiency against ESBL producing bacteria.

This synergy might be attributed to the action of the major compounds of the studied essential oil which is mainly represented by pulegone. Oumzil et al. have compared the antibacterial action of different monoterpenes (limonene, menthone, carvone and pulegone) known for their high antimicrobial properties and concluded that pulegone displays the most potent biocide activity [42]. However the mechanism of action of pulegone is still poorly known, Cox et al. suggested that monoterpenes disrupt the permeability barrier of cell membranes and inhibit respiration [43].

Many mechanisms pathways of essential oil/antibiotics synergism include sequential inhibition of common biochemical pathways, inhibition of protective enzymes, combination of membrane active agents, and use of membranotropic agents, these mechanisms leads to enhance the diffusion of other antimicrobials [44-47]. In addition, recent studies have demonstrated that some plant compounds can effectively inhibit the efflux pumps involved in antibiotic resistance mechanisms [48], which could lead to the restoration of sensitivity to antibiotics and reduce their minimum effective dose and thus their side effects and residues in animal products.

\section{CONCLUSION}

This study allowed concluding that the rich pulegone Algerian Mentha pulegium essential oil showed satisfactory bactericidal properties, and demonstrated that its association with classical antibiotics presents a real potential of synergistic interactions especially against threatening ESBL producing bacteria.

The use of these combinations is an efficient practice to reduce the minimum effective dose of the drugs reducing thus their possible toxic effects and the treatment cost.

Pulegone rich Mentha pulegium essential oil may have a huge potential as food preservative and pharmaceutical additive.

However, further work is necessary to explore the molecular action of pulegone and to understand the cellular mechanisms of their combinations with various antibacterial drugs. 


\section{AUTHORS CONTRIBUTION}

All the authors have contributed in various degrees to conception and design, and/or acquisition of data, and/or analysis and interpretation of data, and/or writing present article.

\section{CONFLICTS OF INTERESTS}

All the author(s): YAHIAOUI Fatima, BENAMEUR Qada and BENMAHDI Meriem Hind declare that there is no conflict of interest regarding the publication of this paper.

\section{REFERENCES}

1. Lavanya S, Kumar S, Maria Joseph N, Sivaraman U. Prevalence of extended spectrum beta-lactamases among Enterobacteriaceae and their antibiogram pattern from various clinical samples. Asian J Pharm Clin Res 2015;8:220-3.

2. Thapa R, Lamichhane P, Banjara MR, Prasad Acharya G. Prevalence of extended spectrum beta lactamase producing uropathogens in pregnant women. Asian J Pharm Clin Res 2015;8:207-10.

3. Chalchat JC, Gorunovic MS, Maksimovic ZA, Petrovic SD. Essential oil of wild growing Mentha pulegium $L$ from Yugoslavia. J Essent Oil Res 2000;12:598-600.

4. Newall CA, Anderson LA, Philipson JD. Herbal medicines. A guide for health care professional. The Pharmaceutical Press: London, United Kingdom; 1996.

5. Franke R, Schilcher H. Medicinal and Aromatic Plants Industrial Profiles. CRC Press; 2005.

6. Kowalchik C, William HH. Rodale's illustrated encyclopedia of herbs. Emmaus, Pennsylvania, USA; 1998.

7. Mahboubi M, Haghi G. Antimicrobial activity and chemical composition of Mentha pulegium L. essential oil. J Ethnopharmaco 2008;119-2:325-7.

8. Teixeira B, Marques A, Ramos C, Batista I, Serrano C, Matos O, et al. European pennyroyal (Mentha pulegium) from portugal: chemical composition of essential oil and antioxidant and antimicrobial properties of extracts and essential oil. Ind Crops Prod 2012;36:81-7.

9. Adams RP. Identification of essential oil components by gas chromatography/mass spectrometry. 4th Edition. Carol Stream, Ill, USA; 2007.

10. Clinical and Laboratory Standards Institute; 2011.

11. Bauer AW, Kirby WM, Sherris JC, Turck M. Antibiotic susceptibility testing by a standardized single disk method. Am J Clin Pathol 1966;45:493-6.

12. Eloff JN. A sensitive and quick method to determine the minimum inhibitory concentration of plant extracts for bacteria. Planta Med 1998;60:1-8.

13. Viljoen A, VanVuuren S, Ernst E, Klepser M, Demirci B, Baser H, et al. Osmitopsis asteriscoides (Asteraceae) the antimicrobial activity and essential oil composition of a cape-dutch remedy. J Ethnopharmacol 2003;88:137-43.

14. Langeveld WT, Veldhuizen EJA, Burt SA. Synergy between essential oil components and antibiotics: a review. Crit Rev Microbiol 2014;40:76-94.

15. Pillai SK, Moellering RC, Eliopoulos GM. Antimicrobial combinations, in antibiotics in laboratory medicine. ed $\mathrm{V}$ Lorian, Philadelphia, USA; 2005.

16. EUCAST: Terminology relating to methods for the determination of susceptibility of bacteria to antimicrobial agents. European Committee for Antimicrobial Susceptibility Testing of the European Society of Clinical Microbiology and Infectious Diseases (EUCAST). CMI 2000;6:503-8.

17. White RL, Burgess DS, Manduru M, Bosso JA. Comparison of three different in vitro methods of detecting synergy: time-kill, checkerboard, and E test. Antimicrob Agents Chemother 1996;40:1914-8.

18. Stoyanova A, Georgiev E, Kula J, Majda T. Chemical composition of the essential oil of Mentha pulegium l. from Bulgaria. J Essent Oil Res 2005;17:475-6.

19. Beghidja N, Bouslimani N, Benayache F, Benayache S, Chalchat JC. Composition of the oils from Mentha pulegium grown in different areas of the East of Algeria. Chem Nat Compd 2007;43:481-3.
20. Mkaddem M, Boussaid M, Fadhel NB. Variability of volatiles in tunisian Mentha pulegium L. (Lamiaceae). J Essent Oil Res 2007;19:211-4.

21. Cherrat L, EspinaL, Bakkali M, Pagán Rand. Laglaouiet a: chemical composition, antioxidant and antimicrobial properties of Mentha pulegium, Lavandula stoechas and Satureja calamintha scheele essential oils and an evaluation of their bactericidal effect in combined process. Innovative Food Sci Emerging Technol 2014;22:221-9.

22. Agnihotri VK, Agarwal SG, Dhar PL,Thappa Baleshwar RK, Kapahi BK, Saxena RK, et al. Essential oil composition of Mentha pulegium L. growing wild in the north-western Himalayas India. Flavour Fragrance J 2005;20:607-10.

23. Nikolic M, Jovanovic KK, Markovic T, Markovic D, Gligorijevic N, Radulovic $\mathrm{S}$, et al. Chemical composition antimicrobial, and cytotoxic properties of five Lamiaceae essential oils. Ind Crops Prod 2014;61:225-32.

24. Morteza-Semnani K, Saeedi M, Akbarzadeh M. Chemical composition and antimicrobial activity of the essential oil of Mentha pulegium L. J Essent Oil-Bear Plants 2011;14:208-13.

25. Khosravi Zanjani MA, Mohammadi N, Zojaji M, Bakhoda H. Chemical composition of the essential oil of Mentha pulegium $\mathrm{L}$ and its antimicrobial activity on Proteus mirabilis, Bacillus subtilis and Zygosaccharomyces rouxii. J Food Biosci Technol 2015;2:31-40.

26. XuP, Jia W, Bi L, Liu X, Zhao Y. Studies on components and quality of essential oil from Mentha piperita L produced in Xinjiang, China. Chem Ind For Prod 2003;23:43-5.

27. Müller Riebau FJ, Berger BM, Yegen O, Cakir C. Seasonal variations in the chemical compositions of essential oils of selected aromatic plants growing wild in Turkey. J Agric Food Chem 1997;45:4821-5.

28. Dorman HJD, Deans SG. Antimicrobial agents from plants: antibacterial activity of plant volatile oils. J Appl Microbiol 2000;88:308-16.

29. Burt S. Essential oils: their antibacterial properties and potential applications in foods-a review. Int J Food Microbiol 2004;94:223-53.

30. Longbottom CJ, Carson CF, Hammer KA, Mee BJ, Riley TV. Tolerance of Pseudomonas aeruginosa to Melaleuca alternifolia (tea tree) oil is associated with the outer membrane and energy-dependent cellular processes. J Antimicrob Chemother 2004;54:386-92.

31. Nikaido Hand Vaara M. Molecular basis of bacterial outer membrane permeability. Microbiol Rev 1985;49:1-32.

32. Karaman I, Sahin F, Gulluce M, Ogutcu H, Sngul M, Adiguzel A. Antimicrobial activity of aqueous and methanol extracts of Juniperus oxycedrus L. J Ethnopharmacol 2003;85:231-5.

33. Dhara L, Tripathi A. Antimicrobial activity of eugenol and cinnamaldehyde against extended spectrum beta lactamase producing Enterobacteriaceae by in vitro and molecular docking analysis. Eur J Integr Med 2013;5:527-36.

34. Rai Mahendra Kumar. Fighting multidrug resistance with herbal extracts, essential oils and their component. K V Kon. San Diego, USA; 2013.

35. Si H, Hu J, Liu Z, Zeng ZL. Antibacterial effect of oregano essential oil alone and in combination with antibiotics against extended-spectrum $\beta$-lactamase-producing Escherichia coli. FEMS Immunol Med Microbiol 2008;53:190-4.

36. Sejal R, Manita W. Antibacterial activity of green tea extract in combination with cefortaxime on diarrhea causing ESBL producing E. coli. Int J Pharm Pharm Sci 2015;7-6:258-62.

37. Marzouk B, Fredj MBH, Chraief I, Mastouri M, Boukef K, Marzouk Z. Chemical composition and antimicrobial activity of essential oils from Tunisian Mentha pulegium L. J Food Agric Environ 2008;6:78-82.

38. Duru ME, Ozturk M, Ugur A, Ceylan O. The constituents of essential oil and in vitro antimicrobial activity of Micromeria cilicica from Turkey. J Ethnopharmacol 2004;94:43-8.

39. Carson CF, Mee BJ, Riley TV. Mechanism of action of Melaleuca alternifolia (tea tree) oil on Staphylococcus aureus determined par time-kill, lysis, leakage and salt tolerance assays and electron microscopy. Antimicrob Agents Chemother 2002;46:1914-20. 
40. Bakkali F, Averbeck S, Averbeck D, Idaomar M. Biological effects of essential oils-a review. Food Chem Toxicol 2008;46:446-75.

41. Shah Pratibha J, Williamson Manita T. Antibacterial activity of honey against ESBL producing Klebsiella pneumoniae from burn wound infections. Int J Curr Pharm Res 2015;7:32-6.

42. Oumzil H, Ghoulami S, Rhajaoui M, Ilidrissi A, Fkih-Tetouani S, Faid M, et al. Antibacterial and antifungal activity of essential oils of Mentha suaveolens. Phytother Res 2002;16:727-31.

43. Cox SD, Mann CM, Markham JL. The mode of antimicrobial action of the essential oil of Melaleuca alternifolia. J Appl Microbiol 2000;88:170-5.

44. Hemaiswarya S, Kruthiventi AK, Doble M. Synergism between natural products and antibiotics against infectious diseases. Phytomedicine 2008;45:639-52.

45. Yap PSX, Yiap BC, Ping HC, Lim SH. Essential oils, a new horizon in combating bacterial antibiotic resistance. Open Microbiol J 2014;8:6-14.
46. Sokolova SM, Buzuk GN, Lovkova MY, Tyutekin YV. Membranotropic compounds and alkaloid accumulation in plants. Dokl Biochem Biophys 2005;402:220-2.

47. Fadli M, Saad A, Sayadi S, Chevalier J, Mezrioui NE, Pagès JM, et al. Antibacterial activity of Thymus maroccanus and Thymus broussonetii essential oilsagainst nosocomial infection-bacteria and their synergistic potential with antibiotics. Phytomedicine 2012;19:464-71.

48. Smith ECJ, Kaatz GW, Seo SM, Wareham N, Williamson EM, Gibbons S. The phenolic diterpenetotarol inhibits multidrug efflux pump activity in Staphylococcus aureus. Antimicrob Agents Chemother 2007;54:4480-3.

\section{How to cite this article}

- Fatima Yahiaoui, Qada Benameur, Meriem Hind Ben-Mahdi. Antibacterial activity of Mentha pulegium essential oil against avian isolated ESBL producing bacteria and its synergistic potential with antibiotics. Int J Pharm Pharm Sci 2017;9(6):35-41. 